\title{
A conceptual framework of virtual team effectiveness from the Socio-Technical perspective
}

\author{
Huynh Thi Minh Chau ${ }^{*}$, Nguyen Manh Tuan ${ }^{1}$ \\ ${ }^{1}$ Ho Chi Minh City University of Technology, Vietnam National University HCMC, Vietnam \\ *Corresponding author: htmchau@ @cmut.edu.vn
}

\begin{tabular}{ll}
\hline \multicolumn{1}{c}{ ARTICLE INFO } & \multicolumn{1}{c}{ ABSTRACT } \\
\hline $\begin{array}{l}\text { DOI:10.46223/HCMCOUJS. } \\
\text { econ.en.8.2.164.2018 }\end{array}$ & $\begin{array}{l}\text { In the era of globalization and technologization, virtual } \\
\text { teamwork has become a routine part of professional activity in the } \\
\text { software industry and other industries. Understanding virtual team } \\
\text { effectiveness helps the management to improve the overall } \\
\text { effectiveness of organizations. In this paper, we conduct a } \\
\text { literature review of team research to set up a conceptual } \\
\text { framework of virtual team effectiveness based on the socio- } \\
\text { technical perspective and Inputs-Mediators-Outputs-Inputs }\end{array}$ \\
$\begin{array}{l}\text { Received: July } 7^{\text {th }}, 2018 \\
\text { Revised: July 30 }{ }^{\text {th }}, 2018\end{array}$ & $\begin{array}{l}\text { model. Our framework includes some salient inputs, mediators } \\
\text { and outputs of virtual team life-cycle; specifically, technology } \\
\text { readiness and intention to explore are two technical antecedents; } \\
\text { team learning and transactive memory system are two social } \\
\text { antecedents; and team performance is a socio-technical output } \\
\text { representing virtual team effectiveness. After that, a 27-item } \\
\text { measuring instrument of aforesaid concepts is proposed after a }\end{array}$ \\
$\begin{array}{l}\text { Keywords: } 16^{\text {th }}, 2018 \\
\text { IMOI model, socio-technical } \\
\text { perspective, team } \\
\text { effectiveness, virtual team }\end{array}$ & $\begin{array}{l}\text { qualitative survey of 19 virtual team leaders and a quantitative } \\
\text { survey of 151 virtual team members from 19 companies locating } \\
\text { in Vietnam. The results are references for those interested in } \\
\text { improving virtual team effectiveness. }\end{array}$ \\
\hline &
\end{tabular}

\section{Introduction}

Thanks to the rapid development and extensive application of information and communication technology, opportunities for collaboration that are offered to the virtual team when it works across time, space and organizational boundaries. It has become an important component of organizations as it enables to cope with the market change and requirement (Bhat, Pande, \& Ahuja, 2017). Researchers have offered many definitions of virtual teams and to some extent the definition of a virtual team can be viewed as completed, however, there are very few definitions of an effective virtual team. Referring to the review of R. Friedrich (2017), in this paper, an effective virtual team is: (1) geographically dispersed (over different time zones); (2) driven by a common purpose; (3) enabled by communication technologies; (4) involved in cross-boundary collaboration; (5) work with the same communication processes. The challenge 
for research is determining how to integrate the contributions of virtual team members to bring added value to its effectiveness. With the aim of supplying more reference to virtual team research, this paper consists of 2 steps: (1) literature review; (2) exploratory research (including a qualitative survey and a quantitative survey).

Firstly, because the virtual team is a special team, team research is reviewed to build up a conceptual framework of virtual team effectiveness. In the team research area, hundreds of primary studies have been conducted, several meta-analyses have been performed, and numerous reviews of the literature have been published. They show that there have been some remarkable types of virtual team effectiveness models. Among them, the IMOI model suggested by Ilgen, Hollenbeck, Johnson, and Jundt (2005) is considered as a considerable development of the IPO model that has been applied widely in virtual team research (Dulebohn \& Hoch, 2017; Mathieu, Maynard, Rapp, \& Gilson, 2008; Rico et al., 2010). The IMOI model employs "M" to reflect the wide range of variables that are important mediational influences on explanatory power for explaining variability in virtual team effectiveness. It also adds the extra "I" at the end of the model to represent the inherent cyclical nature of virtual team functioning by highlighting feedback processes, so that some virtual team's outputs at a given moment represent new inputs for subsequent activity. In this paper, the IMOI model helps us propose an initial framework describing virtual team life-cycle with 02 main parts: (1) antecedents of virtual team effectiveness, including: (i) inputs, and (ii) mediators; (2) virtual team effectiveness, meaning outputs. Secondly, the virtual team includes intercultural-dispersed members and communicates through technology tools instead of face-to-face meetings. It uses technology tools to allow dispersed members to combine their knowledge and skills without the expenses of travel. That's why many multinational companies in both the software industry and other industries utilize virtual team to achieve operational efficiency and improve strategic performance despite it also brings risks (Alsharo, Gregg, \& Ramirez, 2017; Dulebohn \& Hoch, 2017; R. Friedrich, 2017; Osman, 2017). As a virtual team that is social-complex depends on technology, the socio-technical perspective is suitable to study its functioning. In this paper, the socio-technical perspective helps us consider some salient antecedents of virtual team effectiveness as: (1) social antecedents; (2) technical antecedents.

On the method aspect, rather than attempting to provide a comprehensive review of work that has been done in the past, we opt to discuss the evolution and the applications of the IMOI model and socio-technical perspective in studying virtual team effectiveness. Using this foundation, we feature previously selected works that have focused on different representative aspects of the virtual team or provide a vehicle for highlighting some novel findings or approaches. After the literature review, a conceptual framework and inherited scales of identified concepts are specified. Then we conduct exploratory research with a qualitative survey and a quantitative survey to modify inherited scales and propose the measuring instrument. 


\section{Literature review}

\subsection{The IMOI model and its application in virtual team research}

According to the reviews of Mathieu et al. (2008), and Rico et al. (2010), the IMOI model of Ilgen et al. (2005) is the most prominent development of the IPO model which considers team as a multi-level system that contains emergent states resulting from the regular and repeated interaction of their members. Relying on the IMOI model, team research has largely investigated the influences of work team characteristics and team structures on team effectiveness. The IMOI model helps to solve two considerable criticisms of the IPO model: (1) inability to incorporate the temporal and recursive aspects imposed on teams by development and feedback so that it can overlook the adaptive and incremental learning processes that necessarily influence effectiveness; (2) unitary, simplified and opaque treatment of team processes. It is believed that the IMOI model better reflects the functioning of teams as complex adaptive systems operating in broader contexts.

In the IMOI model, (1) inputs describe antecedents that enable and constrain members' interactions. Inputs include the context of the organization, task design/team context, individual-level inputs/team composition inputs. The combination of these various factors influences team processes, which describe members' interactions directed towards task accomplishment. (2) Mediators are also important antecedents because they describe how inputs are transformed into outputs. Mediators include team processes, emergent states, and blended mediators. (3) Outputs are results and by-products of team activity that are valued by one or more stakeholders. Outputs include team performance and members' effect and viability (Mathieu et al., 2008; Rico et al., 2010). Some remarkable inputs, mediators and outputs of team effectiveness mentioned in recent studies are shown in Table 1.

\section{Table 1}

Some remarkable inputs, mediators and outputs of team effectiveness

\begin{tabular}{|c|c|c|}
\hline $\begin{array}{l}\text { Kinds of } \\
\text { factors }\end{array}$ & Factors & Some works that mentioned \\
\hline \multicolumn{3}{|l|}{ Inputs } \\
\hline \multirow{4}{*}{$\begin{array}{l}\text { a. The } \\
\text { context of the } \\
\text { organization }\end{array}$} & $\begin{array}{l}\text { a1. Human resource } \\
\text { systems }\end{array}$ & $\begin{array}{l}\text { Birdi et al. (2008), van Roosmalen (2012), Sharif and } \\
\text { Nahas (2013) }\end{array}$ \\
\hline & a2. Openness climate & $\begin{array}{l}\text { Beltrán-Martín, Roca-Puig, Escrig-Tena, and Bou- } \\
\text { Llusar (2008), Parker (2011), Xue, Bradley, and } \\
\text { Liang (2011) }\end{array}$ \\
\hline & $\begin{array}{l}\text { a3. Multiteam systems } \\
\text { coordination }\end{array}$ & $\begin{array}{l}\text { Mathieu, Maynard, Taylor, Gilson, and Ruddy } \\
\text { (2007), Salas, Goodwin, and Burke (2009) }\end{array}$ \\
\hline & $\begin{array}{l}\text { a4. Top management } \\
\text { team-environment } \\
\text { interface }\end{array}$ & $\begin{array}{l}\text { Cannella, Park, and Lee (2008), Salas et al. (2009), } \\
\text { Guest (2011) }\end{array}$ \\
\hline
\end{tabular}




\begin{tabular}{|c|c|c|}
\hline $\begin{array}{l}\text { Kinds of } \\
\text { factors }\end{array}$ & Factors & Some works that mentioned \\
\hline \multicolumn{3}{|l|}{ Inputs } \\
\hline & $\begin{array}{l}\text { a5. Cultural } \\
\text { influence on teams }\end{array}$ & $\begin{array}{l}\text { Sharif and Nahas (2013), Mueller (2015), Cheng et } \\
\text { al. (2016) }\end{array}$ \\
\hline \multirow{5}{*}{$\begin{array}{l}\text { b. Task } \\
\text { design and } \\
\text { team context }\end{array}$} & b1. Interdependence & $\begin{array}{l}\text { Rico, Alcover, Sánchez-Manzanares, and Gil (2009), } \\
\text { Lee, Lin, Huang, Huang, and Teng (2015) }\end{array}$ \\
\hline & $\begin{array}{l}\text { b2. Technology/ } \\
\text { Virtuality }\end{array}$ & $\begin{array}{l}\text { Salas et al. (2009), Breuer, Hüffmeier, and Hertel } \\
\text { (2016), Schaubroeck and } \mathrm{Yu}(2017)\end{array}$ \\
\hline & $\begin{array}{l}\text { b3. Team training/ } \\
\text { Teambuilding }\end{array}$ & Salas et al. (2008), Hughes et al. (2016) \\
\hline & $\begin{array}{l}\text { b4. Team leadership/ } \\
\text { Coaching }\end{array}$ & $\begin{array}{l}\text { Zaccaro, Heinen, and Shuffler (2009), Grille, } \\
\text { Schulte, and Kauffeld (2015), Moe, Cruzes, Dybå, } \\
\text { and Engebretsen (2015) }\end{array}$ \\
\hline & b5. Team structure & $\begin{array}{l}\text { Kavadias and Sommer (2009), Hoch and Kozlowski } \\
\text { (2014), Glukhov, Ilin, and Levina (2015), Erickson, } \\
\text { Noonan, Carter, McGurn, and Purifoy (2015) }\end{array}$ \\
\hline \multirow[t]{5}{*}{$\begin{array}{l}\text { c. Individual } \\
\text { level inputs/ } \\
\text { Team } \\
\text { composition } \\
\text { inputs }\end{array}$} & c1. Personality & $\begin{array}{l}\text { Jacques, Garger, Brown, and Deale (2009), Prewett, } \\
\text { Walvoord, Stilson, Rossi, and Brannick (2009), } \\
\text { Booth (2011), Cogliser, Gardner, Gavin, and } \\
\text { Broberg (2012), Luse, McElroy, Townsend, and } \\
\text { Demarie (2013) }\end{array}$ \\
\hline & c2. Competencies & $\begin{array}{l}\text { Mohammed, Ferzandi, and Hamilton (2010), Ziek } \\
\text { and Smulowitz (2014) }\end{array}$ \\
\hline & c3. Demographic & $\begin{array}{l}\text { Algesheimer, Dholakia, and Gurău (2011), Booth } \\
\text { (2011), S. T. Bell, Villado, Lukasik, Belau, and } \\
\text { Briggs (2011) }\end{array}$ \\
\hline & c4. Functional diversity & Cannella et al. (2008), Peters and Karren (2009) \\
\hline & c5. Attitudes/values & $\begin{array}{l}\text { De Hoogh and Den Hartog (2008), Mohammed et al. } \\
\text { (2010), Biscaia, Correia, Rosado, Ross, and Maroco } \\
(2013)\end{array}$ \\
\hline \multicolumn{3}{|l|}{ Mediators } \\
\hline \multirow[t]{2}{*}{$\begin{array}{l}\text { d. Team } \\
\text { processes }\end{array}$} & d1. Transition process & $\begin{array}{l}\text { Mathieu and Rapp (2009), T. L. Friedrich, Griffith, } \\
\text { and Mumford (2016) }\end{array}$ \\
\hline & d2. Action processes & $\begin{array}{l}\text { LePine, Piccolo, Jackson, Mathieu, and Saul (2008), } \\
\text { Rothrock, Cohen, Yin, Thiruvengada, and Nahum- } \\
\text { Shani (2009), Berry (2011), Salas, Shuffler, Thayer, } \\
\text { Bedwell, and Lazzara (2015), Ellwart, Happ, } \\
\text { Gurtner, and Rack (2015) }\end{array}$ \\
\hline
\end{tabular}




\begin{tabular}{|c|c|c|}
\hline $\begin{array}{l}\text { Kinds of } \\
\text { factors }\end{array}$ & Factors & Some works that mentioned \\
\hline \multicolumn{3}{|l|}{ Inputs } \\
\hline & $\begin{array}{l}\text { d3. Interpersonal } \\
\text { processes }\end{array}$ & $\begin{array}{l}\text { Gil, Rico, and Sánchez-Manzanares (2008), Liu, } \\
\text { Magjuka, and Lee (2008), Saafein and Shaykhian } \\
\text { (2014), Majchrzak, Rice, King, Malhotra, and Ba } \\
\text { (2014), Hu and Liden (2015) }\end{array}$ \\
\hline & d4. Other processes & LePine et al. (2008), To, Tse, and Ashkanasy (2015) \\
\hline \multirow[t]{6}{*}{$\begin{array}{l}\text { e. Emergent } \\
\text { states }\end{array}$} & e1. Team confidence & $\begin{array}{l}\text { C.-P. Lin, Baruch, and Shih (2012), Zimmermann } \\
\text { and Ravishankar (2014), Ayoko and Chua (2014) }\end{array}$ \\
\hline & e2. Team empowerment & $\begin{array}{l}\text { Hempel, Zhang, and Han (2012), Erkutlu and Chafra } \\
\text { (2012), Maynard, Mathieu, Gilson, O’Boyle, Jr., and } \\
\text { Cigularov (2013), Kukenberger, Mathieu, and Ruddy } \\
\text { (2015) }\end{array}$ \\
\hline & e3. Climate & $\begin{array}{l}\text { Chu-Weininger et al. (2010), Zohar, Huang, Lee, and } \\
\text { Robertson (2014) }\end{array}$ \\
\hline & e4. Cohesion & $\begin{array}{l}\text { Callow, Smith, Hardy, Arthur, and Hardy (2009), } \\
\text { Tekleab, Quigley, and Tesluk (2009), Mach, Dolan, } \\
\text { and Tzafrir (2010) }\end{array}$ \\
\hline & e5. Trust & Mach et al. (2010), Collins and Chou (2013) \\
\hline & e6. Collective cognition & $\begin{array}{l}\text { DeChurch and Mesmer-Magnus (2010), van den } \\
\text { Bossche, Gijselaers, Segers, Woltjer, and Kirschner } \\
\text { (2011) }\end{array}$ \\
\hline \multirow[t]{3}{*}{$\begin{array}{l}\text { f. Blended } \\
\text { mediators }\end{array}$} & f1. Team learning & $\begin{array}{l}\text { Kozlowski and Bell (2008), van den Bossche et al. } \\
\text { (2011), Carmeli, Tishler, and Edmondson (2012), } \\
\text { Kukenberger et al. (2015), Tekleab, Karaca, Quigley, } \\
\text { and Tsang (2016), Kassim and Nor (2017) }\end{array}$ \\
\hline & $\begin{array}{l}\text { f2. Behavioral } \\
\text { integration }\end{array}$ & $\begin{array}{l}\text { Carmeli and Halevi (2009), On, Liang, Priem, and } \\
\text { Shaffer (2013), Tekleab et al. (2016) }\end{array}$ \\
\hline & $\begin{array}{l}\text { f3. Transactive } \\
\text { memory }\end{array}$ & $\begin{array}{l}\text { Choi, Lee, and Yoo (2010), Shatdal and Vohra (2011), } \\
\text { Ren and Argote (2011), Hsu, Shih, Chiang, and Liu } \\
\text { (2012), Zheng (2012), Argote and Ren (2012), } \\
\text { Kotlarsky, van den Hooff, and Houtman (2015), Liao, } \\
\text { O'Brien, Jimmieson, and Restubog (2015), Chung, } \\
\text { Lee, and Han (2015) }\end{array}$ \\
\hline \multicolumn{3}{|l|}{ Outputs } \\
\hline \multirow[t]{2}{*}{$\begin{array}{l}\text { g. Team } \\
\text { performance }\end{array}$} & $\begin{array}{l}\text { g1. Organizational- } \\
\text { level performance }\end{array}$ & $\begin{array}{l}\text { Carmeli et al. (2012), J. Y. Jiang and Liu (2015), X.- } \\
\text { a. Zhang, Li, Ullrich, and van Dick (2015) }\end{array}$ \\
\hline & g2. Team performance & Kukenberger et al. (2015), Owens and Hekman \\
\hline
\end{tabular}




\begin{tabular}{|c|c|c|}
\hline $\begin{array}{c}\text { Kinds of } \\
\text { factors }\end{array}$ & Factors & Some works that mentioned \\
\hline \multicolumn{3}{|l|}{ Inputs } \\
\hline & $\begin{array}{l}\text { behaviors and } \\
\text { outcomes }\end{array}$ & $\begin{array}{l}\text { (2016), Bowers, Oser, Salas, and Cannon-Bowers } \\
\text { (2018) }\end{array}$ \\
\hline & $\begin{array}{l}\text { g3. Role-based } \\
\text { performance }\end{array}$ & $\begin{array}{l}\text { Leroy, Anseel, Gardner, and Sels (2015), Fransen et } \\
\text { al. (2016), Hauer et al. (2016) }\end{array}$ \\
\hline & $\begin{array}{l}\text { g4. Performance } \\
\text { composites }\end{array}$ & C.-P. Lin et al. (2012), Ellwart et al. (2015) \\
\hline \multirow[t]{2}{*}{$\begin{array}{l}\text { h. Members' } \\
\text { effect and } \\
\text { viability }\end{array}$} & $\begin{array}{l}\text { h1. Members' affective } \\
\text { reactions }\end{array}$ & $\begin{array}{l}\text { Li, Li, and Wang (2009), Boies and Howell (2009), } \\
\text { Rozell and Scroggins (2010), Cicei (2012), Rincon et } \\
\text { al. (2012), Zeitun, Abdulqader, and Alshare (2013) }\end{array}$ \\
\hline & h2. Team viability & $\begin{array}{l}\text { Rousseau and Aubé (2010), S. T. Bell and } \\
\text { Marentette (2011), Costa, Passos, and Barata (2015), } \\
\text { Peñarroja, Orengo, and Zornoza (2017) }\end{array}$ \\
\hline
\end{tabular}

Source: The researcher's data analysis

Virtual team has become interesting while having the great number of research in recent years (e.g., Bergiel, Bergiel, \& Balsmeier, 2008; Curşeu, Schalk, \& Wessel, 2008; Dulebohn \& Hoch, 2017; Ebrahim, Ahmed, \& Taha, 2009; R. Friedrich, 2017; Gilson, Maynard, Young, Vartiainen, \& Hakonen, 2015; Hoch \& Dulebohn, 2017; Marlow, Lacerenza, \& Salas, 2017; Mihhailova, 2007). Recently, Dulebohn and Hoch (2017) proposed a conceptual framework of virtual team effectiveness which proved that the IMOI model is also an useful framework to study virtual teams. At first, in that framework, there are three input categories which represent key deterministic criteria for virtual teams: (1) organizational-level factors (B. S. Bell \& Kozlowski, 2002; Hoch \& Kozlowski, 2014); (2) team leadership factors (Kozlowski \& Bell, 2003; Zaccaro, Rittman, \& Marks, 2001); (3) team composition (Driskell \& Salas, 2013; Ferreira, da Rocha, \& da Silva, 2014; Hoch \& Dulebohn, 2013). Next, team process factors and emergent states are mediators of the inputs and outcomes relationship. Team processes refer to team members' interdependent acts of transforming inputs into outcomes. Incontrast, emergent states represent tap qualities of a team, these types of construct characterize properties of the team that are typically dynamic in nature and vary as a function of team context, inputs, processes, and outcomes (Marks, Mathieu, \& Zaccaro, 2001). Next, Dulebohn and Hoch (2017) recognize the differences and the position of emergent states and processes including cognitive processes (such as team cognition and cognitive climate), motivational processes (such as teamwork engagement), effective processes (such as team cohesion) and behavioral processes (such as shared leadership, communication, and technology usage) (Kozlowski \& Bell, 2003; Marks et al., 2001; Mathieu et al., 2008; Zaccaro et al., 2001). Meanwhile, moderators include factors that may moderate the input and team process pathway as well as the team process and outcomes pathway by affecting the direction and/or the strength of the relationships in the model (B. S. Bell \& Kozlowski, 2002; Bowers, Pharmer, \& Salas, 2000; Hambrick, Humphrey, 
\& Gupta, 2015). Finally, outputs represent the effect of the processes transforming team inputs into outcomes that are valued by the organization. Virtual teams generally exist to achieve certain goals, deliverables, performance outcomes, etc. Dulebohn and Hoch (2017) have designated two levels of outcomes: (1) team level outcomes that represent the degree to which the team achieves performance goals and objectives, represented by indicators such as team performance and effectiveness; (2) individual team member outcomes that reflect member performance, effectiveness, and attitudes such as satisfaction and commitment.

\subsection{The socio-technical perspective in virtual team research}

The Socio-Technical System (STS) theory is the most relevant representative of sociotechnical perspective in research. This theory initially mentioned that both the interaction of technology, people and work systems lead to high job satisfaction. If a technical system is created at the expense of a social system, the results obtained will be optimal (Mumford \& Beekman, 1994). Based on the STS theory, socio-technical research is premised on the interdependent and inextricably linked relationships among the features of any technological object or system and the social norms, rules of use and participation by a broad range of human stakeholders. This mutual constitution of technological and social elements is the basis of the term socio-technical system. The mutual constitution directs researchers to consider a phenomenon without making a priori judgments regarding the relative importance or significance of technological or social aspects (Sawyer \& Jarrahi, 2013). Socio-technical system design is based on the premise that an organization or a work unit is a combination of technical and social parts and that it is open to its environment (Trist, Higgin, Murray, \& Pollock, 1963). Because both technical and social elements must work together to accomplish tasks, the key issue of STS theory is to design work so that these two elements yield positive outcomes; this is called joint optimization.

A team in organizations is embedded in a dynamic and complex socio-technical system that influences its behavior and effectiveness. Since the early years of the STS theory, a large number of team research has been launched and based on the joint optimization principle (Molleman \& Broekhuis, 2001). The joint optimization principle deals with the fact that teams endeavor to consider both technical and social aspects simultaneously. At the micro-level, there are numerous factors involved in each aspect. The technical aspect includes, e.g., the processes, tasks, techniques, knowledge and tools used in teamwork. The social aspect includes, e.g., people and their attitudes and behaviors, as well as organizational norms, rules and culture. Mostly, the idea of socio-technical coordination and/or congruence was widely proposed by researchers in software development teams (e.g., Cataldo, Wagstrom, Herbsleb, \& Carley, 2006; L. Jiang, Carley, \& Eberlein, 2012; Madey, Freeh, \& Tynan, 2002; Sarma, Herbsleb, \& van der Hoek, 2008; Valetto et al., 2007; Wolf, Schröter, Damian, Panjer, \& Nguyen, 2009). Besides, the STS theory has also been applied in other fields on team research. According to Appelbaum (1997), the key principles of the STS that have contributed to our understanding of effective team design as follows: (1) overall productivity is directly related to the system's accurate analysis of technical and social needs and requirements; (2) an accurate analysis of 
the technical and social needs usually leads to team designs with the following characteristics: minimal critical specification of rules, multi-skills, boundary location, information flow, support congruence, design and human values. Molleman and Broekhuis (2001) defined STS as an integral theory of work design and quality of working life. By means of the STS theory, they fon out that a kind of team design may help team achieve four different patterns of performance indicators. In other words, with a specific pattern of performance indicators in mind, they depicted a working design as contingent on these three principles. Bélanger, Watson-Manheim, and Swan (2013) explored the STS theory as a foundation for the development of the multilevel conceptual model of telecommuting. They illustrated the use of the model with data from two organizations in the high technology industry before concluding with recommendations for future research. In sum, a socio-technical perspective takes account of technical and social needs that propose ways of achieving joint optimization by designing different kinds of organizations, including team, in which the relationships between technical and social elements lead to the emergence of productivity and wellbeing.

\section{Conceptual framework}

Collectively, the above literature proves that the IMOI model and socio-technical perspective are appropriate for proposing a conceptual framework of virtual team effectiveness in this paper. It would be ideal to consider all socio-technical antecedents of virtual team effectiveness. However, our primary aim is to employ the value of the IMOI framework and socio-technical perspective by combining them into a conceptual framework, so we focus on some salient inputs, mediators of virtual team effectiveness relying on the joint optimization principle. Particularly, technology readiness (a team composition input) and intention to explore (a behavioral process) are two technical antecedents; team learning (a behavioral process) and a transactive memory system (a blended mediator) are two social antecedents. There is an extensive literature that has incorporated team performance as the criterion variable of interest because it has been argued that the definition of a team is that it produces something useful to an organization (Mathieu et al., 2008). In contrast to the works where performance behaviors and outcomes can be differentiated, many studies have used team performance as a composite measure of team outputs. Given that teams perform multiple functions, we use virtual team performance as a performance composite output which may be a good indicator of virtual team effectiveness. Aforesaid socio-technical antecedents are interrelated with the goal of optimizing virtual team members' performance to ultimately improve socio-technical output namely virtual team performance. In sum, there are 5 concepts and 5 hypotheses in our conceptual framework (see Figure 1). 


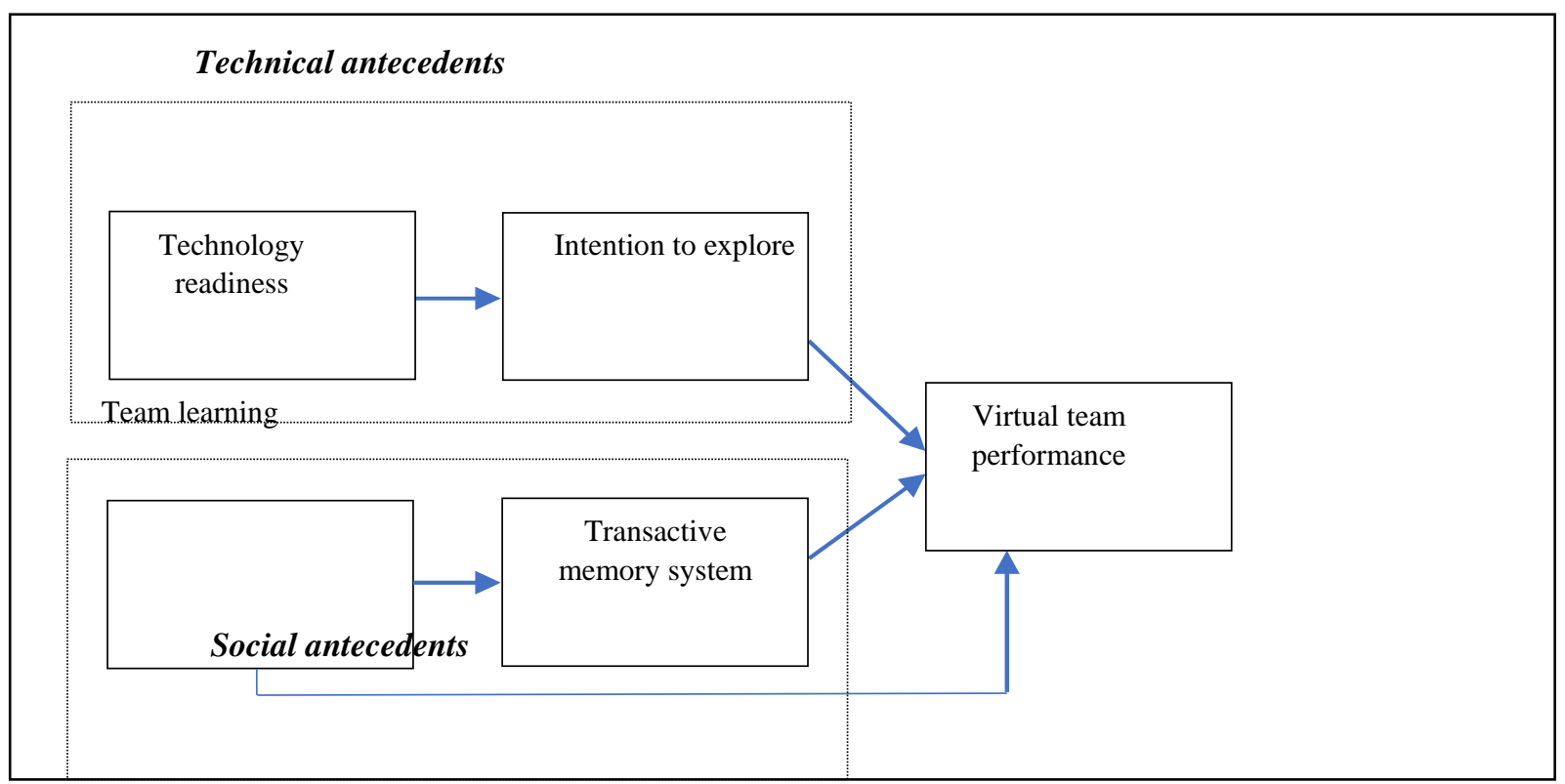

Figure 1. A conceptual framework of virtual team effectiveness under socio-technical perspective

\subsection{Technology readiness: A team composition input}

Among many significant antecedents of technology usage intentions and behaviors, technology readiness (TR) emerges as a concept representing people's propensity to embrace and use new technology for accomplishing goals in home life and at work (Parasuraman, 2000). The TR construct can be viewed as an overall state of mind resulting from a gestalt of mental enablers and inhibitors that collectively determine a person's predisposition to use new technology. It comprises four sub-dimensions: optimism, innovativeness, discomfort, and insecurity. (1) Optimism relates to a positive view of technology and a belief that technology offers people in increased control, flexibility, and efficiency. (2) Innovativeness refers to a tendency to be a technology pioneer and thought leader. (3) Discomfort consists of a perception of lack of control over technology and a feeling of being overwhelmed by it. (4) Insecurity involves distrust of technology and skepticism about its ability to work properly. Optimism and innovativeness are drivers of TR, while discomfort and insecurity are inhibitors. Positive and negative beliefs in technology may coexist, and people can be arrayed along a technology belief continuum from a strongly positive attitude at one end to a strongly negative attitude at the other (C.-H. Lin, Shih, \& Sher, 2007).

The correlation between people's TR and their propensity to employ technology is empirically confirmed by Parasuraman (2000). Consumers' TR has a positive impact on their online service quality perceptions and online behaviors, but empirical findings are scarce (Zeithaml, Parasuraman, \& Malhotra, 2002) and confounded (Liljander, Gillberg, Gummerus, \& van Riel, 2006). The limited knowledge about TR constitutes a need to investigate TR in a broader framework (C.-H. Lin et al., 2007). Thus, studying TR as a team composition input of virtual team functioning could be necessary for virtual team effectiveness research. And 
because of the importance of TR towards technology usage, we propose the first hypothesis: TR has a positive effect on the intention to explore collaboration tools.

\subsection{Intention to explore: A behavioral process}

The virtual team is more complex because its interactions are almost mediated by electronic communication and collaboration technology instead of face-to-face meetings (R. Friedrich, 2017). Technology can support good virtual teamwork and in the virtual team, the agreed and committed working processes are more important to team success (Ebrahim, 2015). Dube and Marnewick (2016) affirmed that in a virtual team, technology usage is an important aspect while team members use technology to coordinate and execute team activities. In an effort of developing the theory and offering new directions to virtual team research, with the goal of making efforts to inform organizations of enhancing the effectiveness of virtual team, they classified virtual team's mediators into four types: cognitive processes (e.g., team cognition and cognitive climate), motivational processes (e.g., teamwork engagement), affective processes (e.g., team cohesion) and behavioral processes (e.g., shared leadership, communication, and technology usage). It means that technology usage should be studied as a behavioral process of virtual team effectiveness.

Managers have had difficulty identifying potential levers that affect employees' willingness to engage in innovative behaviors with newly implemented technologies (Ahuja \& Thatcher, 2005; Jasperson, Carter, \& Zmud, 2005). Intention to explore is defined as one's willingness and purpose to explore new technology and find a potential use (Nambisan, Agarwal, \& Tanniru, 1999) - reflects employees' propensity for engaging in exploration behavior. This intention can lead to the discovery of methods for leveraging the technology to support one's work and the result is a higher team performance (Maruping \& Magni, 2012). Because of the importance of the intention to explore virtual team effectiveness, we propose the second hypothesis: The intention to explore collaboration tools has a positive effect on virtual team performance.

\subsection{Team learning: A behavioral process}

Since Senge (1990) proclaimed that teams, not individuals, are the fundamental learning unit in modern organizations, there has been an ongoing shift from work organized around individual jobs to team-based work systems (Devine, 1999). Teams bring diverse skills, expertise, and experience needed to tackle increasingly complex and dynamic organizational problems together. They enable more rapid and flexible responses to the technological, economic, and political pressures faced by modern organizations. In addition, teams facilitate collaboration and share knowledge across organizational, cultural, and spatiotemporal boundaries. The emergence of teams as the basic building blocks of organizations has been accompanied by growing interest in the topic of team learning (B. S. Bell, Kozlowski, \& Blawath, 2012). It is our literature review to discover that in team research, the construct of team learning is usually understood as a behavioral process (Mathieu et al., 2008; Rico et al., 2010), it is said that it represents an ongoing process of reflection and action, through which teams acquire, share, combine, and apply knowledge (Kozlowski \& Bell, 2008). 
The virtual team offers a viable response to expertise constraints created by downsizing, mergers and acquisitions, globalization, and employee mobility preferences. Moreover, it promises new possibilities of leveraging and integrating relevant and diverse knowledge across an organization, and thus is steadily favored for accomplishing complex and nuanced knowledge work requiring multi-perspective inputs (Soule \& Applegate, 2009). Virtual team members who work collaboratively, out of necessity, are more likely to gain valuable knowledge to develop their expertise hence optimizing their performance (Ebrahim, Ahmed, Abdul-Rashid, \& Taha, 2011; Liu et al., 2008). Accordingly, the virtual team's ability to learn becomes remarkably important to establish and sustain effectiveness. In virtual team learning, (1) internal team learning means that team members bring knowledge, skills and experience to the workplace and attribute them to the team level; while (2) external team learning means outsourcing to solve the problems encountered by team (Edmondson \& Nembhard, 2009). These rationales prove that virtual team learning should be studied as a behavioral process that leads to virtual team performance, it means that we are able to propose the third hypothesis: Team learning has a positive effect on virtual team performance.

\subsection{Transactive memory system: A blend mediator}

A Transactive Memory System (TMS) has been defined as the combination of individual memory systems and communications (also referred to as "transactions") between individuals. TMS is constituted by individuals using each other as a memory source. Transactions between individuals link their memory systems: through a series of processes (i.e., encoding, storing and retrieving) knowledge is exchanged between individuals and, in turn, gaps in knowledge are reduced. The majority of past studies on TMS have studied the influence of TMS on performance (e.g., Akgun, Byrne, Keskin, \& Lynn, 2006; Lewis, 2004; Lewis, Lange, \& Gillis, 2005; Yoo \& Kanawattanachai, 2001) or have focused on antecedents that facilitate development of TMS (e.g., Akgun, Byrne, Keskin, Lynn, \& Imamoglu, 2005; Brandon \& Hollingshead, 2004; Moreland \& Myaskovsky, 2000). Previous studies proved that TMS can play an intermediate role in the relationship of team learning and team performance.

For example, Liang, Moreland, and Argote (1995) indicated that team training and communicating can positively improve team performance primarily by creating TMS among team members; using similar experimental training conditions, Moreland and Myaskovsky (2000) argued that TMS not only mediates the relationship between training behaviors and outcomes but also improves the inter-personal communication process; conceptualizing TMS as a learning system, Lewis et al. (2005) suggested that a TMS helps members learn, both individually and collectively, as well as affect team knowledge transfer to produce sustained performance; several recent studies on TMS (e.g., Jarvenpaa \& Majchrzak, 2008; Todorova, Argote, \& Reagans, 2008) concluded that effectiveness of knowledge sharing among team members is dependent on the intensity of internal TMS; Z.-X. Zhang, Hempel, Han, and Tjosvold (2007) proved the mediating role of TMS in the relationship between team characteristics and effectiveness. In light of the close link between learning behaviors and team effectiveness, we propose the following hypotheses: Team learning has a positive effect on TMS, and TMS has a positive effect on virtual team performance. 


\section{Exploratory research}

\subsection{Qualitative survey}

\subsubsection{Methods}

At first, we build up a 36-item scale of 5 proposed concepts, including 16 items adapted from Parasuraman and Colby (2015) to measure TR, 3 items adapted from Maruping and Magni (2012) to measure intention to explore, 9 items adapted from Chan, Pearson, and Entrekin (2003) to measure team learning, 3 items adapted from Yoo and Kanawattanachai (2001) to measure TMS, and 5 items adapted from Hoegl, Weinkauf, and Gemuenden (2004) to measure virtual team performance. Then we conduct 19 in-depth interviews (face-to-face or via telephone) on 19 virtual team leaders from 19 companies locating in Vietnam (Appivity System, Csc Vietnam, Dek Vietnam, DTT Vietbando, Elca, Groove Technology Vietnam, Hrboss Vietnam, Hunter Macdonald Vietnam, Phonak Operation Center Vietnam, Quantic, Saic, Vng Corp, EVNHCMC, EVN SPC, Duy Tan Plastics, Huong Ngoc Lan Cosmetics, Nguyen Minh Steels, Inox Tien Dat, Van Thanh E\&I). The sample size is determined by saturation (Saunders, 2012). A semi-structured questionnaire is used. It takes about 60-90 minutes per interview.

\subsubsection{Results}

The first prominent result is 12/19 interviewees eliminated 8 measuring variables of 2 dimensions in TR: discomfort and insecurity. They believe that negative beliefs about technology may make them confused about the intention to explore (although these variables will be reversed). 15/19 interviewees believe that the satisfaction of using collaboration tools for teamwork is a noteworthy output that influences their intention to explore in the future. Thus, we add one more item to the scale of Hoegl et al. (2004) to measure virtual team performance: "In general, we feel satisfied with the overall experience of using collaboration tools for teamwork". The above elimination and supplement are accepted by all interviewees afterwards. Moreover, there are also some changes in using words, such as: (1) "group" is modified to "team"; (2) "my colleagues" and "team members" are modified to "my teammates"; (3) "organization" and "department" are modified to "company"; (4) "the system" are modified to "collaboration tools"; (5) "my team", "this team" and "the team" are modified to "our team". Finally, the measuring scale after a qualitative survey includes 29 variables (see Table 3).

\subsection{Quantitative survey}

\subsubsection{Methods}

A quantitative survey is conducted by means of questionnaires that contain 2 demographic questions (team type, team size) and 29 measuring questions using Likert 5-point scale. To acquire the data sample, members who work in virtual teams in 19 aforesaid companies. Convenience sampling is used, the data is collected by sending emails to respondents. 200 questionnaires are sent out and 151 are found appropriate. Data is analyzed by SPSS.

\subsubsection{Results}

The demographic characteristics of respondents are shown in Table 2. 
Table 2

Demographics

\begin{tabular}{|l|c|l|}
\hline \multicolumn{1}{|c|}{ Details } & $\mathbf{N}$ & \multicolumn{1}{c|}{ Percentage } \\
\hline Team size & 151 & $\begin{array}{l}\bullet \text { From 2 to 10 members: } 125(82.8 \%) \\
\text { - More than 10 members: } 26(17.2 \%)\end{array}$ \\
\hline Team type & 151 & $\begin{array}{l}\bullet \text { Software development teams: } 118(78.1 \%) \\
\bullet\end{array}$ \\
\hline
\end{tabular}

Source: The researcher's data analysis

The first exploratory factor analysis (EFA) eliminates 1 indicator, namely TL6 of team learning and VTP3 of virtual team performance whereas the EFA's factor loading $<0.50$ (Hair, Black, Babin, \& Anderson, 2013). Then, the second EFA has extracted 5 elements from 27 indicators, including technology readiness, team learning, intention to explore, transactive memory system virtual team performance. The factor loading of all indicators ranges from 0.725 to 0.912 . Furthermore, the Kaiser Meyer Olkin $(\mathrm{KMO})=0.782$; Chi-square $(\mathrm{v} 2)=$ 212.207; Bartlett test of sphericity, $\mathrm{dF}=136(\mathrm{p}=0.000)$. These indexes provide that the EFA of the all observational variables is appropriate (Hair et al., 2013), so the measurement scale is valuable. Nevertheless, the total variance extracted (TVA) $=75.72 \%$ that explains the difference in the data roughly $75.72 \%$. Besides, Cronbach's Alpha of all 5 factors $>0.6$, and each indicator has an inter-item correlation $>0.3$ thus no indicator is eliminated and the scale is reliable (see Table 3). In sum, this 27-item measuring scale may be useful for further analysis, including confirmatory factor analysis (CFA), structural equation modeling (SEM), and Bootstrap analysis.

Table 3

Proposed measuring instrument

\begin{tabular}{|c|c|c|c|c|}
\hline Factors & \multicolumn{2}{|r|}{$\begin{array}{c}\text { Measuring variables after qualitative } \\
\text { survey }\end{array}$} & $\begin{array}{l}\text { Factor } \\
\text { loading }\end{array}$ & $\begin{array}{c}\text { Cronbach's } \\
\text { Alpha }\end{array}$ \\
\hline \multirow{5}{*}{ 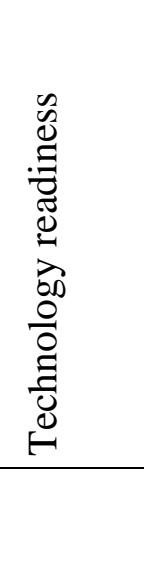 } & TR1 & $\begin{array}{l}\text { New technologies contribute to a better quality of } \\
\text { life }\end{array}$ & 0.900 & \multirow[t]{4}{*}{0.813} \\
\hline & TR2 & Technology gives me more freedom of mobility & 0.887 & \\
\hline & TR4 & $\begin{array}{l}\text { Technology makes me more productive in my } \\
\text { personal life }\end{array}$ & 0.836 & \\
\hline & TR3 & $\begin{array}{l}\text { Technology gives people more control over their } \\
\text { daily lives }\end{array}$ & 0.810 & \\
\hline & TR6 & $\begin{array}{l}\text { In general, I am among the first in my circle of } \\
\text { friends to acquire new technology when it appears }\end{array}$ & 0.800 & \\
\hline
\end{tabular}




\begin{tabular}{|c|c|c|c|c|}
\hline \multirow[t]{4}{*}{ Factors } & \multicolumn{2}{|r|}{$\begin{array}{c}\text { Measuring variables after qualitative } \\
\text { survey }\end{array}$} & \multirow{2}{*}{$\begin{array}{c}\begin{array}{c}\text { Factor } \\
\text { loading }\end{array} \\
0.791\end{array}$} & \multirow[t]{2}{*}{$\begin{array}{c}\text { Cronbach's } \\
\text { Alpha }\end{array}$} \\
\hline & TR8 & $\begin{array}{l}\text { I keep up with the latest technological } \\
\text { developments in my areas of interest }\end{array}$ & & \\
\hline & TR5 & $\begin{array}{l}\text { Other people come to me for advice on new } \\
\text { technologies }\end{array}$ & 0.739 & \\
\hline & TR7 & $\begin{array}{l}\text { I can figure out new high-tech products and } \\
\text { services without help from others }\end{array}$ & 0.725 & \\
\hline \multirow{8}{*}{ } & TL4 & $\begin{array}{l}\text { In our team, someone always makes sure that we } \\
\text { stop to reflect on our work process }\end{array}$ & 0.912 & \multirow[t]{8}{*}{0.712} \\
\hline & TL3 & $\begin{array}{l}\text { Problems and errors in our team are never } \\
\text { communicated to the appropriate people so that } \\
\text { corrective action can be taken }\end{array}$ & 0.886 & \\
\hline & TL2 & $\begin{array}{l}\text { We regularly take time to figure out ways to } \\
\text { improve our work processes }\end{array}$ & 0.834 & \\
\hline & TL1 & $\begin{array}{l}\text { In our team, people discuss ways to prevent and } \\
\text { learn from mistakes }\end{array}$ & 0.820 & \\
\hline & TL7 & $\begin{array}{l}\text { Our team keeps others in the organization informed } \\
\text { about what we plan and accomplish }\end{array}$ & 0.799 & \\
\hline & TL5 & $\begin{array}{l}\text { People in our team often speak up to test } \\
\text { assumptions about issues under discussion }\end{array}$ & 0.783 & \\
\hline & TL9 & $\begin{array}{l}\text { We invite outsiders to present information or have } \\
\text { discussion with us }\end{array}$ & 0.747 & \\
\hline & TL8 & $\begin{array}{l}\text { My teammates go out and get all the relevant work } \\
\text { information they can from others, such as } \\
\text { customers, or other parts of the company }\end{array}$ & 0.726 & \\
\hline \multirow{3}{*}{ 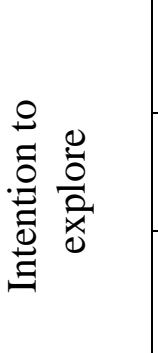 } & IE1 & $\begin{array}{l}\text { I intend to explore how collaboration tools can be } \\
\text { used for other tasks. }\end{array}$ & 0.870 & \multirow[t]{3}{*}{0.766} \\
\hline & IE3 & $\begin{array}{l}\text { I intend to spend time and effort in exploring } \\
\text { collaboration tools for potential applications. }\end{array}$ & 0.856 & \\
\hline & IE2 & $\begin{array}{l}\text { I intend to explore other ways that collaboration } \\
\text { tools may enhance my effectiveness. }\end{array}$ & 0.798 & \\
\hline \multirow{2}{*}{ 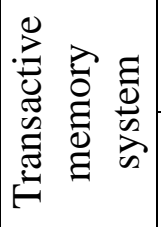 } & $\begin{array}{c}\text { TMS } \\
1\end{array}$ & $\begin{array}{l}\text { Our team has a good "map" of each member's } \\
\text { talents and skills }\end{array}$ & 0.886 & \multirow[t]{2}{*}{0.863} \\
\hline & $\begin{array}{c}\mathrm{TMS} \\
2\end{array}$ & $\begin{array}{l}\text { Our teammates know what task-related skills and } \\
\text { knowledge they possess }\end{array}$ & 0.845 & \\
\hline
\end{tabular}




\begin{tabular}{|c|c|c|c|c|}
\hline \multirow[t]{2}{*}{ Factors } & \multicolumn{2}{|r|}{$\begin{array}{c}\text { Measuring variables after qualitative } \\
\text { survey }\end{array}$} & \multirow{2}{*}{$\begin{array}{c}\begin{array}{c}\text { Factor } \\
\text { loading }\end{array} \\
0.832\end{array}$} & \multirow[t]{2}{*}{$\begin{array}{l}\text { Cronbach's } \\
\text { Alpha }\end{array}$} \\
\hline & $\begin{array}{c}\text { TMS } \\
3\end{array}$ & $\begin{array}{l}\text { Our teammates know who has specialized skills } \\
\text { and knowledge that is relevant to their work. }\end{array}$ & & \\
\hline \multirow{5}{*}{ 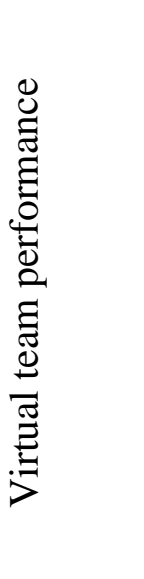 } & VTP5 & $\begin{array}{l}\text { The project leadership can be fully satisfied with } \\
\text { the task progress of our team }\end{array}$ & 0.901 & \multirow[t]{5}{*}{0.754} \\
\hline & VTP1 & $\begin{array}{l}\text { Going by the current status, our team can be } \\
\text { regarded as successful }\end{array}$ & 0.885 & \\
\hline & VTP2 & So far, all team goals have been achieved & 0.863 & \\
\hline & VTP4 & $\begin{array}{l}\text { Our team is satisfied with its performance to this } \\
\text { point }\end{array}$ & 0.856 & \\
\hline & VTP6 & $\begin{array}{l}\text { In general, we feel satisfied with the overall } \\
\text { experience of using ICT tools for teamwork }\end{array}$ & 0.789 & \\
\hline
\end{tabular}

Source: The researcher's data analysis

\section{Conclusion}

\subsection{Key findings}

Our first contribution is proposing a conceptual framework of virtual team effectiveness under a socio-technical perspective. By means of combining the IMOI framework with the STS theory, we focus on identifying some salient socio-technical antecedents of virtual team effectiveness. There are 5 concepts in the proposed framework, including 1 team composition input (technology readiness), 2 behavioral processes (intention to explore, team learning), 1 blended mediator (transactive memory system), and 1 performance composite output (virtual team performance). Among them, technology readiness and intention to explore are 2 technical antecedents, team learning and transactive memory system are 2 social antecedents, and virtual team performance is 1 socio-technical output which represents virtual team effectiveness. The inherent cyclical nature of virtual team functioning and the joint optimization of socio-technical factors of virtual team effectiveness are reflected through multi-relationships between these factors. Besides, our second contribution is proposing a 27 -item measuring instrument by adapting previous scales and conducting a qualitative survey of 19 virtual team leaders and a quantitative survey of 151 virtual team members from 19 companies locating in Vietnam. These results can be used as references for those interested in improving virtual team effectiveness.

\subsection{Further developments}

The recent development of this paper is exploiting data by CFA, SEM and Bootstrap analyses. Moreover, further developments are: (1) make a broader and deeper literature review with more reference documents to explore more interesting factors that represent sociotechnical antecedents of virtual team effectiveness; (2) conduct larger qualitative research on more representative sample to modify measuring variables; (3) carry out quantitative research 
with probability sampling and afterwards use various data analysis tools to verify the research model. The resultant research model with high reliability and validity can be applied widely for measuring and checking virtual team effectiveness in Vietnam through its verified sociotechnical antecedents.

\section{ACKNOWLEDGEMENT}

This research is funded by Ho Chi Minh City University of Technology - VNU-HCM under grant number T- QLCN-2017-103.

\section{References}

Ahuja, M. K., \& Thatcher, J. B. (2005). Moving beyond intentions and toward the theory of trying: Effects of work environment and gender on post-adoption information technology use. MIS Quarterly, 29(3), 427-459. doi:10.2307/25148691

Akgun, A. E., Byrne, J. C., Keskin, H., Lynn, G. S., \& Imamoglu, S. Z. (2005). Knowledge networks in new product development projects: A transactive memory perspective. Information \& Management, 42(8), 1105-1120. doi:10.1016/j.im.2005.01.001

Akgun, A. E., Byrne, J. C., Keskin, H., \& Lynn, G. S. (2006). Transactive memory system in new product development teams. IEEE Transactions on Engineering Management, 53(1), 95-111. doi:10.1109/TEM.2005.857570

Algesheimer, R., Dholakia, U. M., \& Gurău, C. (2011). Virtual team performance in a highly competitive environment. Group \& Organization Management, 36(2), 161-190. doi:10.1177/1059601110391251

Alsharo, M., Gregg, D., \& Ramirez, R. (2017). Virtual team effectiveness: The role of knowledge sharing and trust. Information \& Management, 54(4), 479-490. doi:10.1016/j.im.2016.10.005

Appelbaum, S. H. (1997). Socio-technical systems theory: An intervention strategy for organizational development. Management Decision, 35(6), 452-463. doi:10.1108/00251749710173823

Argote, L., \& Ren, Y. (2012). Transactive memory systems: A microfoundation of dynamic capabilities. Journal of Management Studies, 49(8), 1375-1382. doi:10.1111/j.14676486.2012.01077.x

Ayoko, O. B., \& Chua, E. L. (2014). The importance of transformational leadership behaviors in team mental model similarity, team efficacy, and intra-team conflict. Group \& Organization Management, 39(5), 504-531. doi:10.1177/1059601114550080

Bélanger, F., Watson-Manheim, M. B., \& Swan, B. R. (2013). A multi-level socio-technical systems telecommuting framework. Behaviour and Information Technology, 32(12), 1257-1279. 
Bell, B. S., \& Kozlowski, S. W. J. (2002). A Typology of Virtual teams: Implications for Effective Leadership. Group \& Organization Management, 27(1), 22. doi:10.1177/1059601102027001003

Bell, B. S., Kozlowski, S. W. J., \& Blawath, S. (2012). Team learning: A theoretical integration and review. In S. W. J. Kozlowski (Ed.), The Oxford handbook of organizational psychology (Vol. 2, pp. 859-909). Oxford, UK: Oxford University Press.

Bell, S. T., \& Marentette, B. J. (2011). Team viability for long-term and ongoing organizational teams. Organizational Psychology Review, 1(4), 275-292. doi: $10.1177 / 2041386611405876$

Bell, S. T., Villado, A. J., Lukasik, M. A., Belau, L., \& Briggs, A. L. (2011). Getting specific about demographic diversity variable and team performance relationships: A metaanalysis. Journal of Management, 37(3), 709-743. doi:10.1177/0149206310365001

Beltrán-Martín, I., Roca-Puig, V., Escrig-Tena, A., \& Bou-Llusar, J. C. (2008). Human resource flexibility as a mediating variable between high performance work systems and

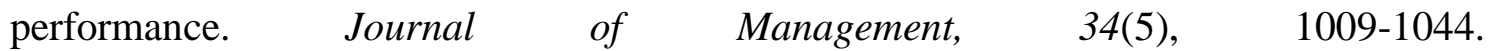
doi: $10.1177 / 0149206308318616$

Bergiel, B. J., Bergiel, E. B., \& Balsmeier, P. W. (2008). Nature of virtual teams: A summary of their advantages and disadvantages. Management Research News, 31(2), 99-110. doi:10.1108/01409170810846821

Berry, G. R. (2011). Enhancing effectiveness on virtual teams: Understanding why traditional team skills are insufficient. The Journal of Business Communication, 48(2), 186-206. doi:10.1177/0021943610397270

Bhat, S. K., Pande, N., \& Ahuja, V. (2017). Virtual team effectiveness: An empirical study using SEM. Procedia Computer Science, 122, 33-41. doi:10.1016/j.procs.2017.11.338

Birdi, K., Clegg, C., Patterson, M., Robinson, A., Stride, C. B., Wall, T. D., \& Wood, S. (2008). The impact of human resource and operational management practices on company productivity: A longitudinal study. Personnel Psychology, 61(3), 467-501. doi:10.1111/j.1744-6570.2008.00136

Biscaia, R., Correia, A., Rosado, A. F., Ross, S. D., \& Maroco, J. (2013). Sport sponsorship: The relationship between team loyalty, sponsorship awareness, attitude toward the sponsor, and purchase intentions. Journal of Sport Management, 27(4), 288-302. doi:10.1123/jsm.27.4.288

Boies, K., \& Howell, J. M. (2009). Leading military teams to think and feel: Exploring the relations between leadership, soldiers' cognitive and affective processes, and team effectiveness. Military Psychology, 21(2), 216-232. doi:10.1080/08995600902768743

Booth, B. (2011). Examining the critical factors of success in virtual team performance (Doctoral dissertation, University of Northcentral, United States). Retrieved March 10, 2018, from https://eric.ed.gov/?id=ED525269 
Bowers, C. A., Pharmer, J. A., \& Salas, E. (2000). When member homogeneity is needed in work teams: A meta-analysis. Small Group Research, 31(3), 305-327. doi:10.1177/104649640003100303

Bowers, C. A., Oser, R. L., Salas, E., \& Cannon-Bowers, J. A. (2018). Team performance in automated systems. In R. Parasuraman, \& M. Mouloua (Eds.), Automation and human performance: Theory and applications. Boca Raton, Florida: CRC Press.

Brandon, D. P., \& Hollingshead, A. B. (2004). Transactive memory systems in organizations: Matching tasks, expertise, and people. Organization Science, 15(6), 633-644. doi:10.1287/orsc.1040.0069

Breuer, C., Hüffmeier, J., \& Hertel, G. (2016). Does trust matter more in virtual teams? A metaanalysis of trust and team effectiveness considering virtuality and documentation as moderators. Journal of Applied Psychology, 101(8), 1151-1177. doi:10.1037/ap10000113

Callow, N., Smith, M. J., Hardy, L., Arthur, C. A., \& Hardy, J. (2009). Measurement of transformational leadership and its relationship with team cohesion and performance level. Journal of Applied Sport Psychology, 21(4), 395-412. doi:10.1080/10413200903204754

Cannella, A. A., Jr., Park, J.-H., \& Lee, H.-U. (2008). Top management team functional background diversity and firm performance: Examining the roles of team member colocation and environmental uncertainty. Academy of Management Journal, 51(4), 768784. doi:10.5465/AMR.2008.33665310

Carmeli, A., \& Halevi, M. Y. (2009). How top management team behavioral integration and behavioral complexity enable organizational ambidexterity: The moderating role of contextual ambidexterity. The Leadership Quarterly, 20(2), 207-218. doi:10.1016/j.leaqua.2009.01.011

Carmeli, A., Tishler, A., \& Edmondson, A. C. (2012). CEO relational leadership and strategic decision quality in top management teams: The role of team trust and learning from failure. Strategic Organization, 10(1), 31-54. doi:10.1177/1476127011434797

Cataldo, M., Wagstrom, P. A., Herbsleb, J. D., \& Carley, K. M. (2006). Identification of coordination requirements: Implications for the design of collaboration and awareness tools. Paper presented at the Proceedings of the 20th anniversary conference on Computer supported cooperative work, Banff, Alberta, Canada, November 4-8.

Chan, C. C., Pearson, C., \& Entrekin, L. (2003). Examining the effects of internal and external team learning on team performance. Team Performance Management: An International Journal, 9(7/8), 174-181. doi:10.1108/13527590310507426

Cheng, X., Fu, S., Sun, J., Han, Y., Shen, J., \& Zarifis, A. (2016). Investigating individual trust in semi-virtual collaboration of multicultural and unicultural teams. Computers in Human Behavior, 62, 267-276. doi:10.1016/j.chb.2016.03.093 
Choi, S. Y., Lee, H., \& Yoo, Y. (2010). The impact of information technology and transactive memory systems on knowledge sharing, application, and team performance: A field study. MIS Quarterly, 34(4), 855-870. doi:10.2307/25750708

Chu-Weininger, M. Y. L., Wueste, L., Lucke, J. F., Weavind, L., Mazabob, J., \& Thomas, E. J. (2010). The impact of a tele-ICU on provider attitudes about teamwork and safety climate. Qual Saf Health Care, 19(6), e39-e39. doi:10.1136/qshc.2007.024992

Chung, N., Lee, S., \& Han, H. (2015). Understanding communication types on travel information sharing in social media: A transactive memory systems perspective. Telematics and Informatics, 32(4), 564-575. doi:10.1016/j.tele.2015.02.002

Cicei, C. C. (2012). Assessing member's satisfaction in virtual and face-to-face learning teams. Procedia - Social and Behavioral Sciences, 46, 4466-4470. doi:10.1016/j.sbspro.2012.06.278

Cogliser, C. C., Gardner, W. L., Gavin, M. B., \& Broberg, J. C. (2012). Big five personality factors and leader emergence in virtual teams: Relationships with team trustworthiness, member performance contributions, and team performance. Group \& Organization Management, 37(6), 752-784. doi:10.1177/1059601112464266

Collins, N., \& Chou, Y. (2013). Building team trust: A study in the Asian context. The Journal of American Business Review, Cambridge, 1(2), 181-188.

Costa, P. L., Passos, A. M., \& Barata, M. C. (2015). Multilevel influences of team viability perceptions. Team Performance Management, 21(1/2), 19-36. doi:10.1108/TPM-032014-0020

Curşeu, P. L., Schalk, R., \& Wessel, I. (2008). How do virtual teams process information? A literature review and implications for management. Journal of Managerial Psychology, 23(6), 628-652. doi:10.1108/02683940810894729

DeChurch, L. A., \& Mesmer-Magnus, J. R. (2010). Measuring shared team mental models: A meta-analysis. Group Dynamics: Theory, Research, and Practice, 14(1), 1-14. doi:10.1037/a0017455

De Hoogh, A. H., \& Den Hartog, D. N. (2008). Ethical and despotic leadership, relationships with leader's social responsibility, top management team effectiveness and subordinates' optimism: A multi-method study. The Leadership Quarterly, 19(3), 297-311. doi:10.1016/j.leaqua.2008.03.002

Devine, D. J. (1999). Effects of cognitive ability, task knowledge, information sharing, and conflict on group decision-making effectiveness. Small Group Research, 30(5), 608-634. doi:10.1177/104649649903000506

Driskell, J. E., \& Salas, E. (2013). Stress and human performance. London, UK: Psychology Press. 
Dube, S., \& Marnewick, C. (2016). A conceptual model to improve performance in virtual teams. South African Journal of Information Management, 18(1), 1-10. doi:10.4102/sajim.v18i1.674

Dulebohn, J. H., \& Hoch, J. E. (2017). Virtual teams in organizations. Human Resource Management Review, 27(4), 569-574. doi:10.1016/j.hrmr.2016.12.004

Ebrahim, N. A. (2015). Virtual R\&D teams: A new model for product development. International Journal of Innovation, 3(2), 1-27. doi:10.5585/iji.v3i2.43

Ebrahim, N. A., Ahmed, S., Abdul-Rashid, S. H., \& Taha, Z. (2011). Virtual collaborative R\&D teams in Malaysia manufacturing SMEs. Paper presented at 2nd International Conference on Mechanical, Industrial, and Manufacturing Technologies (MIMT 2011), February 2628, Hotel Royal, Singapore.

Ebrahim, N. A., Ahmed, S., \& Taha, Z. (2009). Virtual teams: A literature review. Australian Journal of Basic and Applied Sciences, 3(3), 2653-2669.

Edmondson, A. C., \& Nembhard, I. M. (2009). Product development and learning in project teams: The challenges are the benefits. Journal of Product Innovation Management, 26(2), 123-138. doi:10.1111/j.1540-5885.2009.00341.x

Ellwart, T., Happ, C., Gurtner, A., \& Rack, O. (2015). Managing information overload in virtual teams: Effects of a structured online team adaptation on cognition and performance. European Journal of Work and Organizational Psychology, 24(5), 812-826. doi:10.1080/1359432X.2014.1000873

Erickson, A. G., Noonan, P., Carter, K. S., McGurn, L., \& Purifoy, E. (2015). The team functioning scale: Evaluating and improving effectiveness of school teams. International Journal of Educational Research, 69, 1-11. doi:10.1016/j.ijer.2014.09.001

Erkutlu, H., \& Chafra, J. (2012). The impact of team empowerment on proactivity: The moderating roles of leader's emotional intelligence and proactive personality. Journal of Health Organization and Management, 26(5), 560-577. doi:10.1108/14777261211256918

Ferreira, J. B., da Rocha, A., \& da Silva, J. F. (2014). Impacts of technology readiness on emotions and cognition in Brazil. Journal of Business Research, 67(5), 865-873. doi:10.1016/j.jbusres.2013.07.005

Fransen, K., Steffens, N. K., Haslam, S. A., Vanbeselaere, N., Vande Broek., \& Boen, F. (2016). We will be champions: Leaders' confidence in 'us' inspires team members team confidence and performance. Scandinavian Journal of Medicine \& Science in Sports, 26(12), 1455-1469. doi:10.1111/sms.12603

Friedrich, T. L., Griffith, J. A., \& Mumford, M. D. (2016). Collective leadership behaviors: Evaluating the leader, team network, and problem situation characteristics that influence their use. The Leadership Quarterly, 27(2), 312-333. doi:10.1016/j.leaqua.2016.02.004 
Friedrich, R. (2017). The virtual team maturity model: Performance improvement of virtual teams. Berlin, Germany: Springer.

Gil, F., Rico, R., \& Sánchez-Manzanares, M. (2008). Eficacia de equipos de trabajo. Papeles del psicólogo, 29(1), 25-31.

Gilson, L. L., Maynard, M. T., Young, N. C. J., Vartiainen, M., \& Hakonen, M. (2015). Virtual teams research: 10 years, 10 themes, and 10 opportunities. Journal of Management, 41(5), 1313-1337. doi:10.1177/0149206314559946

Glukhov, V. V., Ilin, I. V., \& Levina, A. I. (2015). Project management team structure for internet providing companies. Paper presented at the Conference on Smart Spaces. Springer International Publishing.

Grille, A., Schulte, E.-M., \& Kauffeld, S. (2015). Promoting shared leadership: A multilevel analysis investigating the role of prototypical team leader behavior, psychological empowerment, and fair rewards. Journal of Leadership \& Organizational Studies, 22(3), 324-339. doi:10.1177/1548051815570039

Guest, D. E. (2011). Human resource management and performance: Still searching for some answers. Human Resource Management Journal, 21(1), 3-13. doi:10.1111/j.17488583.2010.00164.x

Hair, J. F., Black, W. C., Babin, B. J., \& Anderson, R. E. (2013). Multivariate data analysis: Pearson new international edition. London, UK: Pearson

Hambrick, D. C., Humphrey, S. E., \& Gupta, A. (2015). Structural interdependence within top management teams: A key moderator of upper echelons predictions. Strategic Management Journal, 36(3), 449-461. doi:10.1002/smj.2230

Hauer, K. E., Cate, O. T., Boscardin, C. K., Iobst, W., Holmboe, E. S., Chesluk, B., ... O'Sullivan, P. S. (2016). Ensuring resident competence: A narrative review of the literature on group decision making to inform the work of clinical competency committees. Journal of Graduate Medical Education, 8(2), 156-164. doi:10.4300/JGMED-15-00144.1

Hempel, P. S., Zhang, Z.-X., \& Han, Y. (2012). Team empowerment and the organizational context: Decentralization and the contrasting effects of formalization. Journal of Management, 38(2), 475-501. doi:10.1177/0149206309342891

Hoch, J. E., \& Dulebohn, J. H. (2013). Shared leadership in enterprise resource planning and human resource management system implementation. Human Resource Management Review, 23(1), 114-125. doi:10.1016/j.hrmr.2012.06.007

Hoch, J. E., \& Kozlowski, S. W. (2014). Leading virtual teams: Hierarchical leadership, structural supports, and shared team leadership. Journal of Applied Psychology, 99(3), 390. doi:10.1037/a0030264 
Hoch, J. E., \& Dulebohn, J. H. (2017). Team personality composition, emergent leadership and shared leadership in virtual teams: A theoretical framework. Human Resource Management Review, 27(4), 678-693. doi:10.1016/j.hrmr.2016.12.012

Hoegl, M., Weinkauf, K., \& Gemuenden, H. G. (2004). Interteam coordination, project commitment, and teamwork in multiteam R\&D projects: A longitudinal study. Organization Science, 15(1), 38-55. doi:10.1287/orsc.1030.0053

Hsu, J. S.-C., Shih, S.-P., Chiang, J. C., \& Liu, J. Y.-C. (2012). The impact of transactive memory systems on IS development teams' coordination, communication, and performance. International Journal of Project Management, 30(3), 329-340. doi:10.1016/j.ijproman.2011.08.003

Hu, J., \& Liden, R. C. (2015). Making a difference in the teamwork: Linking team prosocial motivation to team processes and effectiveness. Academy of Management Journal, 58(4), 1102-1127. doi:10.5465/amj.2012.1142

Hughes, A. M., Gregory, M. E., Joseph, D. L., Sonesh, S. C., Marlow, S. L., Lacerenza, C. N., ... Salas, E. (2016). Saving lives: A meta-analysis of team training in healthcare. Journal of Applied Psychology, 101(9), 1266-1304. doi:10.1037/ap10000120

Ilgen, D. R., Hollenbeck, J. R., Johnson, M., \& Jundt, D. (2005). Teams in organizations: From Input-Process-Output models to IMOI models. Annual Review of Psychology, 56, 517543. doi:10.1146/annurev.psych.56.091103.070250

Jacques, P. H., Garger, J., Brown, C. A., \& Deale, C. S. (2009). Personality and virtual reality team candidates: The roles of personality traits, technology anxiety and trust as predictors of perceptions of virtual reality teams. Journal of Business and Management, 15(2), 143.

Jarvenpaa, S. L., \& Majchrzak, A. (2008). Knowledge collaboration among professionals protecting national security: Role of transactive memories in ego-centered knowledge networks. Organization Science, 19(2), 260-276. doi:10.1287/orsc.1070.0315

Jasperson, J. S., Carter, P. E., \& Zmud, R. W. (2005). A comprehensive conceptualization of post-adoptive behaviors associated with information technology enabled work systems. MIS Quarterly, 29(3), 525-557. doi:10.2307/25148694

Jiang, J. Y., \& Liu, C.-W. (2015). High performance work systems and organizational effectiveness: The mediating role of social capital. Human Resource Management Review, 25(1), 126-137. doi:10.1016/j.hrmr.2014.09.001

Jiang, L., Carley, K. M., \& Eberlein, A. (2012). Assessing team performance from a sociotechnical congruence perspective. Paper presented at the Proceedings of the International Conference on Software and System Process, Zurich Switzerland.

Kassim, N. A., \& Nor, A. M. (2017). Team learning in a learning organization: The practices of team learning among university librarians in Malaysia. Malaysian Journal of Library \& Information Science, 12(1), 55-64. 
Kavadias, S., \& Sommer, S. C. (2009). The effects of problem structure and team diversity on brainstorming effectiveness. Management Science, 55(12), 1899-1913. doi: $10.1287 / \mathrm{mnsc} .1090 .1079$

Kotlarsky, J., van den Hooff, B., \& Houtman, L. (2015). Are we on the same page? Knowledge boundaries and transactive memory system development in cross-functional teams. Communication Research, 42(3), 319-344. doi:10.1177/0093650212469402

Kozlowski, S. W. J., \& Bell, B. S. (2003). Work groups and teams in organizations. In W. C. Borman, D. R. Ilgen \& R. J. Klimoski (Eds.), Handbook of psychology (Vol. 12, pp. 333375). New York, NY: Wiley-Blackwell.

Kozlowski, S. W. J., \& Bell, B. S. (2008). Team learning, development, and adaptation. In V. I. Sessa \& M. London (Eds.), Work group learning (pp. 15-44). Mahwah, NJ: LEA.

Kukenberger, M. R., Mathieu, J. E., \& Ruddy, T. (2015). A cross-level test of empowerment and process influences on members' informal learning and team commitment. Journal of Management, 41(3), 987-1016. doi:10.1177/0149206312443559

Lee, C.-c., Lin, Y.-h., Huang, H.-c., Huang, W.-w., \& Teng, H.-h. (2015). The effects of task interdependence, team cooperation, and team conflict on job performance. Social Behavior and Personality: An International Journal, 43(4), 529-536. doi:10.2224/sbp.2015.43.4.529

LePine, J. A., Piccolo, R. F., Jackson, C. L., Mathieu, J. E., \& Saul, J. R. (2008). A metaanalysis of teamwork processes: Tests of a multidimensional model and relationships with team effectiveness criteria. Personnel Psychology, 61(2), 273-307. doi:10.1111/j.1744-6570.2008.00114.X

Leroy, H., Anseel, F., Gardner, W. L., \& Sels, L. (2015). Authentic leadership, authentic followership, basic need satisfaction, and work role performance: A cross-level study. Journal of Management, 41(6), 1677-1697. doi:10.1177/0149206312457822

Lewis, K. (2004). Knowledge and performance in knowledge-worker teams: A longitudinal study of transactive memory systems. Management Science, 50(11), 1519-1533. doi:10.1287/mnsc. 1040.0257

Lewis, K., Lange, D., \& Gillis, L. (2005). Transactive memory systems, learning, and learning transfer. Organization Science, 16(6), 581-598. doi:10.1287/orsc.1050.0143

Li, F., Li, Y., \& Wang, E. (2009). Task characteristics and team performance: The mediating effect of team member satisfaction. Social Behavior and Personality: An International Journal, 37(10), 1373-1382. doi:10.2224/sbp.2009.37.10.1373

Liang, D. W., Moreland, R., \& Argote, L. (1995). Group versus individual training and group performance: The mediating role of transactive memory. Personality and Social Psychology Bulletin, 21(4), 384-393. doi:10.1177/0146167295214009 
Liao, J., O’Brien, A. T., Jimmieson, N. L., \& Restubog, S. L. D. (2015). Predicting transactive memory system in multidisciplinary teams: The interplay between team and professional identities. Journal of Business Research, 68(5), 965-977. doi:10.1016/j.jbusres.2014.09.024

Liljander, V., Gillberg, F., Gummerus, J., \& van Riel, A. (2006). Technology readiness and the evaluation and adoption of self-service technologies. Journal of Retailing and Consumer Services, 13(3), 177-191. doi:10.1016/j.jretconser.2005.08.004

Lin, C.-H., Shih, H.-Y., \& Sher, P. J. (2007). Integrating technology readiness into technology acceptance: The TRAM model. Psychology \& Marketing, 24(7), 641-657. doi:10.1002/mar.20177

Lin, C.-P., Baruch, Y., \& Shih, W.-C. (2012). Corporate social responsibility and team performance: The mediating role of team efficacy and team self-esteem. Journal of Business Ethics, 108(2), 167-180. doi:10.1007/s10551-011-1068-6

Liu, X., Magjuka, R. J., \& Lee, S.-h. (2008). The effects of cognitive thinking styles, trust, conflict management on online students' learning and virtual team performance. British Journal of Educational Technology, 39(5), 829-846. doi:10.1111/j.14678535.2007.00775.x

Luse, A., McElroy, J. C., Townsend, A. M., \& Demarie, S. (2013). Personality and cognitive style as predictors of preference for working in virtual teams. Computers in Human Behavior, 29(4), 1825-1832. doi:10.1016/j.chb.2013.02.007

Mach, M., Dolan, S. L., \& Tzafrir, S. (2010). The differential effect of team members' trust on team performance: The mediation role of team cohesion. Journal of Occupational and Organizational Psychology, 83(3), 771-794. doi:10.1348/096317909X473903

Madey, G., Freeh, V., \& Tynan, R. (2002). The open source software development phenomenon: An analysis based on social network theory. AMCIS 2002 Proceedings, 247.

Majchrzak, A., Rice, R. E., King, N., Malhotra, A., \& Ba, S. (2014). Computer-mediated interorganizational knowledge-sharing: Insights from a virtual team innovating using a collaborative tool. Information Resources Management Journal, 13(1), 44-53. doi:10.4018/irmj.2000010104

Marks, M. A., Mathieu, J. E., \& Zaccaro, S. J. (2001). A temporally based framework and taxonomy of team processes. Academy of Management Review, 26(3), 356-376. doi:10.5465/amr.2001.4845785

Marlow, S. L., Lacerenza, C. N., \& Salas, E. (2017). Communication in virtual teams: A conceptual framework and research agenda. Human Resource Management Review, 27(4), 575-589. doi:10.1016/j.hrmr.2016.12.005 
Maruping, L. M., \& Magni, M. (2012). What's the weather like? The effect of team learning climate, empowerment climate, and gender on individuals' technology exploration and use. Journal of Management Information Systems, 29(1), 79-114. doi:10.2753/MIS07421222290103

Mathieu, J. E., Maynard, M. T., Rapp, T., \& Gilson, L. L. (2008). Team effectiveness 19972007: A review of recent advancements and a glimpse into the future. Journal of Management, 34(3), 410-476. doi:10.1177/0149206308316061

Mathieu, J. E., Maynard, M. T., Taylor, S. R., Gilson, L. L., \& Ruddy, T. M. (2007). An examination of the effects of organizational district and team contexts on team processes and performance: A meso-mediational model. Journal of Organizational Behavior, 28(7), 891-910. doi:10.1002/job.480

Mathieu, J. E., \& Rapp, T. L. (2009). Laying the foundation for successful team performance trajectories: The roles of team charters and performance strategies. Journal of Applied Psychology, 94(1), 90-103. doi:10.1037/a0013257

Maynard, M. T., Mathieu, J. E., Gilson, L. L., O’Boyle, E. H., Jr, \& Cigularov, K. P. (2013). Drivers and outcomes of team psychological empowerment: A meta-analytic review and model test. Organizational Psychology Review, 3(2), 101-137. doi: $10.1177 / 2041386612456868$

Mihhailova, G. (2007). Virtual teams - just a theoretical concept or a widely used practice? The Business Review, 7(1), 186-192.

Moe, N. B., Cruzes, D. S., Dybå, T., \& Engebretsen, E. (2015). Coaching a global agile virtual team. Paper presented at 2015 IEEE 10th International Conference on Global Software Engineering, Ciudad Real, 2015.

Mohammed, S., Ferzandi, L., \& Hamilton, K. (2010). Metaphor no more: A 15-year review of the team mental model construct. Journal of Management, 36(4), 876-910. doi: $10.1177 / 0149206309356804$

Molleman, E., \& Broekhuis, M. (2001). Sociotechnical systems: Towards an organizational learning approach. Journal of Engineering and Technology Management, 18(3/4), 271294. doi:10.1016/S0923-4748(01)00038-8

Moreland, R. L., \& Myaskovsky, L. (2000). Exploring the performance benefits of group training: Transactive memory or improved communication? Organizational Behavior and Human Decision Processes, 82(1), 117-133. doi:10.1006/obhd.2000.2891

Mueller, J. (2015). Formal and informal practices of knowledge sharing between project teams and enacted cultural characteristics. Project Management Journal, 46(1), 53-68. doi:10.1002/pmj.21471

Mumford, E., \& Beekman, G. (1994). Tools for change \& progress. Netherlands: CSG Publications. 
Nambisan, S., Agarwal, R., \& Tanniru, M. (1999). Organizational mechanisms for enhancing user innovation in information technology. MIS Quarterly, 23(3), 365-395. doi: $10.2307 / 249468$

On, L. W., Liang, X., Priem, R., \& Shaffer, M. (2013). Top management team trust, behavioral integration and the performance of international joint ventures. Journal of Asia Business Studies, 7(2), 99-122. doi:10.1108/15587891311319413

Osman, H. (2017). The ultimate list of virtual team technology tools. Retrieved February 20, 2018, from https://www.thecouchmanager.com/the-ultimate-list-of-virtual-teamtechnology-tools/

Owens, B. P., \& Hekman, D. R. (2016). How does leader humility influence team performance? Exploring the mechanisms of contagion and collective promotion focus. Academy of Management Journal, 59(3), 1088-1111. doi:10.5465/amj.2013.0660

Parasuraman, A. (2000). Technology Readiness Index (TRI) a multiple-item scale to measure readiness to embrace new technologies. Journal of Service Research, 2(4), 307-320. doi:10.1177/109467050024001

Parasuraman, A., \& Colby, C. L. (2015). An updated and streamlined technology readiness index: TRI 2.0. Journal of Service Research, 18(1), 59-74. doi:10.1177/1094670514539730

Parker, G. M. (2011). Team players and teamwork: New strategies for developing successful collaboration. New York, NY: John Wiley \& Sons Inc.

Peñarroja, V., Orengo, V., \& Zornoza, A. (2017). Reducing perceived social loafing in virtual teams: The effect of team feedback with guided reflexivity. Journal of Applied Social Psychology, 47(8), 424-435. doi:10.1111/jasp.12449

Peters, L., \& Karren, R. J. (2009). An examination of the roles of trust and functional diversity on virtual team performance ratings. Group \& Organization Management, 34(4), 479504. doi:10.1177/1059601107312170

Prewett, M. S., Walvoord, A. A., Stilson, F. R., Rossi, M. E., \& Brannick, M. T. (2009). The team personality-team performance relationship revisited: The impact of criterion choice, pattern of workflow, and method of aggregation. Human Performance, 22(4), 273-296. doi:10.1080/08959280903120253

Ren, Y., \& Argote, L. (2011). Transactive memory systems 1985-2010: An integrative framework of key dimensions, antecedents, and consequences. The Academy of Management Annals, 5(1), 189-229. doi:10.1080/19416520.2011.590300

Rico, R., Alcover, C.-M., Sánchez-Manzanares, M., \& Gil, F. (2009). The joint relationships of communication behaviors and task interdependence on trust building and change in virtual project teams. Social Science Information, 48(2), 229-255. doi: $10.1177 / 0539018409102410$ 
Rico, C. M., Pincet, F., Thiery, J. P., \& Dufour, S. (2010). Integrins stimulate E-cadherinmediated intercellular adhesion by regulating Src-kinase activation and actomyosin contractility. Journal of Cell Science, 123, 712-722.

Rico, R., de la Hera, C. M. A., \& Tabernero, C. (2011). Work team effectiveness, a review of research from the last decade (1999-2009). Psychology in Spain, 15(1), 57-79.

Rincon, F., Vibbert, M., Childs, V., Fry, R., Caliguri, D., Urtecho, J., ... Jallo, J. (2012). Implementation of a model of robotic tele-presence (RTP) in the neuro-ICU: Effect on critical care nursing team satisfaction. Neurocritical Care, 17(1), 97-101. doi:10.1007/s12028-012-9712-2

Rothrock, L., Cohen, A., Yin, J., Thiruvengada, H., \& Nahum-Shani, I. (2009). Analyses of team performance in a dynamic task environment. Applied Ergonomics, 40(4), 699-706. doi:10.1016/j.apergo.2008.06.004

Rousseau, V., \& Aubé, C. (2010). Team self-managing behaviors and team effectiveness: The moderating effect of task routineness. Group \& Organization Management, 35(6), 751781. doi:10.1177/1059601110390835

Rozell, E. J., \& Scroggins, W. A. (2010). How much is too much? The role of emotional intelligence in self-managed work team satisfaction and group processes. Team Performance Management: An International Journal, 16(1/2), 33-49. doi:10.1108/13527591011028915

Saafein, O., \& Shaykhian, G. A. (2014). Factors affecting virtual team performance in telecommunication support environment. Telematics and Informatics, 31(3), 459-462. doi:10.1016/j.tele.2013.10.004

Salas, E., DiazGranados, D., Klein, C., Burke, C. S., Stagl, K. C., Goodwin, G. F., \& Halpin, S. M. (2008). Does team training improve team performance? A meta-analysis. Human Factors, 50(6), 903-933. doi:10.1518/001872008X375009

Salas, E., Goodwin, G. F., \& Burke, C. S. (2009). Team effectiveness in complex organizations: Cross-disciplinary perspectives and approaches. England, UK: Routledge.

Salas, E., Shuffler, M. L., Thayer, A. L., Bedwell, W. L., \& Lazzara, E. H. (2015). Understanding and improving teamwork in organizations: A scientifically based practical guide. Human Resource Management, 54(4), 599-622. doi:10.1002/hrm.21628

Sarma, A., Herbsleb, J., \& van der Hoek, A. (2008). Challenges in measuring, understanding, and achieving social-technical congruence. Paper presented at the Proceedings of SocioTechnical Congruence Workshop, In Conjunction with the International Conference on Software Engineering.

Saunders, M. N. (2012). Choosing research participants. In G. Symon, \& C. Cassell (Eds.), Qualitative organizational research: Core methods and current challenges (pp. 37-55). London, UK: Sage. 
Sawyer, S., \& Jarrahi, M. H. (2013). Sociotechnical approaches to the study of information systems. In A. Tucker, \& H. Topi (Eds.), Handbook of Computing. New York, NY: Chapman and Hall.

Schaubroeck, J. M., \& Yu, A. (2017). When does virtuality help or hinder teams? Core team characteristics as contingency factors. Human Resource Management Review, 27(4), 635647. doi:10.1016/j.hrmr.2016.12.009

Senge, P. (1990). The fifth discipline: The art and science of the learning organization. New York, NY: Currency Doubleday.

Sharif, T., \& Nahas, R. (2013). Team effectiveness: A case study of a fast-growing private educational organization in the UAE. Journal of Education \& Practice, 4(22), 141-148.

Shatdal, A., \& Vohra, N. (2011). How information sharing in groups changes with passage of time: A transactive memory perspective. Indore Management Journal, 3(3), 12-18.

Soule, D. L., \& Applegate, L. M. (2009). Virtual team learning: Reflecting and acting, alone or with others (Harvard Business School Working Paper, 09(084)). Retrieved April 20, 2017, from https://www.hbs.edu/faculty/Pages/item.aspx?num=35114

Tekleab, A. G., Quigley, N. R., \& Tesluk, P. E. (2009). A longitudinal study of team conflict, conflict management, cohesion, and team effectiveness. Group \& Organization Management, 34(2), 170-205. doi:10.1177/1059601108331218

Tekleab, A. G., Karaca, A., Quigley, N. R., \& Tsang, E. W. (2016). Re-examining the functional diversity-performance relationship: The roles of behavioral integration, team cohesion, and team learning. Journal of Business Research, 69(9), 3500-3507. doi:10.1016/j.jbusres.2016.01.036

To, M. L., Tse, H. H. M., \& Ashkanasy, N. M. (2015). A multilevel model of transformational leadership, affect, and creative process behavior in work teams. The Leadership Quarterly, 26(4), 543-556. doi:10.1016/j.leaqua.2015.05.005

Todorova, G., Argote, L., \& Reagans, R. (2008). Working alone or together? Individual motivation, group identification and the development of transactive memory systems. Academy of Management Annual Meeting Proceedings, 1-6. doi:10.5465/AMBPP.2008.33725598

Trist, E., Higgin, G., Murray, H., \& Pollock, A. (1963). The assumption of ordinariness as a denial mechanism: Innovation and conflict in a coal mine. In Organizational choice (pp. 476-493). London, UK: Tavistock.

Valetto, G., Helander, M., Ehrlich, K., Chulani, S., Wegman, M., \& Williams, C. (2007). Using software repositories to investigate socio-technical congruence in development projects. Paper presented at the Proceedings of the Fourth International Workshop on Mining Software Repositories, Minneapolis, MN, 2007. 
van den Bossche, P., Gijselaers, W., Segers, M., Woltjer, G., \& Kirschner, P. (2011). Team learning: Building shared mental models. Instructional Science, 39(3), 283-301. doi:10.1007/s11251-010-9128-3

van Roosmalen, T. M. (2012). The development of a questionnaire on the subjective experience of teamwork, based on Salas, Sims and Burke's" the big five of teamwork" and Hackman's understanding of team effectiveness. Norges teknisk-naturvitenskapelige universitet, Fakultet for samfunnsvitenskap og teknologiledelse, Psykologisk institutt (Master's thesis, Norwegian University Of Science And Technology, Norway). Retrieved from https://ntnuopen.ntnu.no/ntnu-xmlui/handle/11250/270920

Wolf, T., Schröter, A., Damian, D., Panjer, L. D., \& Nguyen, T. H. (2009). Mining task-based social networks to explore collaboration in software teams. IEEE Software, 26(1), 58-66. doi:10.1109/MS.2009.16

Xue, Y., Bradley, J., \& Liang, H. (2011). Team climate, empowering leadership, and knowledge sharing. Journal of Knowledge Management, 15(2), 299-312. doi:10.1108/13673271111119709

Yoo, Y., \& Kanawattanachai, P. (2001). Developments of transactive memory systems and collective mind in virtual teams. The International Journal of Organizational Analysis, 9(2), 187-208. doi:10.1108/eb028933

Zaccaro, S. J., Rittman, A. L., \& Marks, M. A. (2001). Team leadership. The Leadership Quarterly, 12(4), 451-483. doi:10.1016/S1048-9843(01)00093-5

Zaccaro, S. J., Heinen, B., \& Shuffler, M. (2009). Team leadership and team effectiveness. In E. Salas, G. F. Goodwin, \& C. S. Burke (Eds.), The organizational frontiers series. Team effectiveness in complex organizations: Cross-disciplinary perspectives and approaches, (pp. 83-111). England, UK: Routledge.

Zeithaml, V. A., Parasuraman, A. P., \& Malhotra, A. (2002). Service quality delivery through web sites: A critical review of extant knowledge. Journal of the Academy of Marketing Science, 30(4), 362-375. doi:10.1177/009207002236911

Zeitun, R. M., Abdulqader, K. S., \& Alshare, K. A. (2013). Team satisfaction and student group performance: A cross-cultural study. Journal of Education for Business, 88(5), 286-293. doi:10.1080/08832323.2012.701243

Zhang, X.-a., Li, N., Ullrich, J., \& van Dick, R. (2015). Getting everyone on board: The effect of differentiated transformational leadership by CEOs on top management team effectiveness and leader-rated firm performance. Journal of Management, 41(7), 18981933.

Zhang, Z.-X., Hempel, P. S., Han, Y.-L., \& Tjosvold, D. (2007). Transactive memory system links work team characteristics and performance. Journal of Applied Psychology, 92(6), 1722-1730. doi:10.1037/0021-9010.92.6.1722 
Zheng, Y. (2012). Unlocking founding team prior shared experience: A transactive memory system perspective. Journal of Business Venturing, 27(5), 577-591. doi:10.1016/j.jbusvent.2011.11.001

Ziek, P., \& Smulowitz, S. (2014). The impact of emergent virtual leadership competencies on team effectiveness. Leadership \& Organization Development Journal, 35(2), 106-120. doi:10.1108/LODJ-03-2012-0043

Zimmermann, A., \& Ravishankar, M. (2014). Knowledge transfer in IT offshoring relationships: The roles of social capital, efficacy and outcome expectations. Information Systems Journal, 24(2), 167-202. doi:10.1111/isj.12027

Zohar, D., Huang, Y.-h., Lee, J., \& Robertson, M. (2014). A mediation model linking dispatcher leadership and work ownership with safety climate as predictors of truck driver safety performance. Accident Analysis \& Prevention, 62, 17-25. doi:10.1016/j.aap.2013.09.005 